\title{
UTJECAJ MIJEŠANJA NA UČINKOVITOST PROCESA KOAGULACIJE I FLOKULACIJE PRI KONDICIONIRANJU VODE VODOCRPILIŠTA „JARČEVAC“
}

\author{
Mirna Habuda-Stanić \\ Sveučilište Josipa Jurja Strossmayera u Osijeku, Prehrambeno-tehnološki fakultet Osijek, docent \\ Marija Nujić
}

Sveučilište Josipa Jurja Strossmayera u Osijeku, Prehrambeno-tehnološki fakultet Osijek, mag.ing.

Gorana Mikić, mag.ing.

Željka Romić

"Vodovod-Osijek" d.o.o., Osijek, dr.sc.

Marija Ivić

"Dvorac" d.o.o., Valpovo, dipl.ing.

Sažetak: Najvažniji izvori vode za piće na području istočne Hrvatske su podzemne vode koje karakterizira visoka tvrdoća i povišene koncentracije željeza, amonija, mangana, arsena i organskih tvari, što negativno utječe na organoleptička svojstva i zdravstvenu ispravnost vode za piće. Jedan od procesa koji se često primjenjuje pri kondicioniranju vode je koagulacija i flokulacija uz naknadnu filtraciju. Na učinkovitost navedenog procesa utječu čimbenici poput fizikalno-kemijskih karakteristika sirove vode, doza i vrsta koagulanta te brzina i vrijeme miješanja u pojedinim fazama navedenog procesa. $U$ ovom radu ispitan je utjecaj brzine i vremena miješanja koagulanata i vode na učinkovitost koagulacije i flokulacije pri obradi aerirane podzemne vode vodocrpilišta „Jarčevac" s dva željezova koagulanta - željezov klorid i željezov(II) sufat te je praćen utjecaj brzine i vremena miješanja na učinak procesa kroz dva seta, uz početnu pH vrijednost vode od 7.5 i početnu koncentraciju ukupnog željeza od $4 \mathrm{mg} / \mathrm{l}$. Učinkovitost je praćena mjerenjem polaznih i završnih vrijednosti količine organskih tvari, ukupne tvrdoće, alkaliteta i koncentracije ukupnog željeza te $\mathrm{pH}$ vrijednosti i vodljivosti vode. S obzirom na dobivene rezultate moguće je zaključiti da je učinkovitija obrada podzemne vode vodocrpilišta "Jarčevac" postignuta pri doziranju željezova klorida.

Ključne riječi: kondicioniranje vode, koagulacija i flokulacija, željezovi koagulanti, miješanje

\section{INFLUENCE OF MIXING ON EFFICIENCY OF COAGULATION AND FLOCCULATION PROCESS DURING GROUNDWATER TREATMENT FROM „JARČEVAC“ WATER- WELL}

\begin{abstract}
Groundwater is the most important source of drinking water in eastern Croatia and it is characterized with high water hardness and elevated concentrations of iron, manganese, arsenic and natural organic matter which negatively affects aesthetic properties and health safety of drinking water. Drinking water quality standards can be achieved by coagulation and flocculation processes followed by filtration. Efficiency of this method is influenced by chemical and physical properties of raw water, type and dose of coagulant, mixing intensity and mixing time. This study investigated the influence of mixing intensity and mixing time on performance of coagulation and flocculation process for aerated low-turbid groundwater from water-well "Jarčevac". Influence of mixing was tested using two iron-based coagulants (ferric chloride and ferrous sulfate). Samples were mixed in two sets at constant pH of 7.5 and constant initial total iron concentration. Efficiency of coagulation and flocculation process was determined based on initial and final value of following parameters: amount of natural organic matter, water hardness, alkalinity, concentration of total iron, $\mathrm{pH}$ and electrical conductivity. Obtained results showed that ferric chloride is more efficient for treatment of groundwater from "Jarčevac" water-well.
\end{abstract}

Key words: drinking water treatment, coagulation and flocculation, iron-based coagulants, mixing 


\section{Uvod}

Podzemne i površinske vode osnovni su resursi vode za piće koji u ovom stoljeću opće globalizacije dodatno dobivaju na važnosti. Naime, desetljeća lošeg gospodarenja vodnim resursima rezultirala su narušavanjem fizikalno-kemijske i mikrobiološke kakvoće vodnih resursa te je, u svrhu postizanja zdravstveno ispravne vode za piće, danas neizbježna primjena pojedinih procesa pri njezinom kondicioniranju. Pravilnikom o parametrima sukladnosti i metodama analize vode za ljudsku potrošnju [1] i aktima Europske unije donesenima na temelju Direktive Vijeća 1998/83/EZ [2] propisani su pojedini mikrobiološki, kemijski i indikatorski parametri, odnosno njihove maksimalno dozvoljene vrijednosti kojima mora udovoljavati voda da bi bila pogodna za ljudsku potrošnju. Radi udovoljavanja odredbama navedenog Pravilnika i Direktive, pri kondicioniranju vode najčešće se primjenjuju sljedeći procesi: taloženje, koagulacija i flokulacija, konvencionalna i membranska filtracija, mekšanje vode, ionska izmjena i dezinfekcija vode [3,4].

Proces koagulacije i flokulacije uz naknadnu filtraciju primjenjuje se radi uklanjanja koloidnih čestica iz vode koje karakteriziraju vrlo male dimenzije $\left(1 \times 10^{-6} \mathrm{~m}\right)$ i negativni naboj koji uzrokuje njihovu dugotrajnu stabilnost u koloidnim suspenzijama, odnosno, sprječava taloženje istih. Proces koagulacije i flokulacije temelji se na doziranju određenih kemijskih tvari, tzv. koagulanata, koji uzrokuju destabilizaciju, agregaciju i međusobno povezivanje koloidnih čestica, što uzrokuje njihovo taloženje pod utjecajem gravitacije (slika 1). Navedeni proces sastoji se od: koagulacije - koja podrazumijeva neutralizaciju negativnog naboja koloidnih čestica, odnosno njihovu destabilizaciju, te flokulacije - koja podrazumijeva agregaciju, međusobno povezivanje i taloženje koloidnih čestica [3].

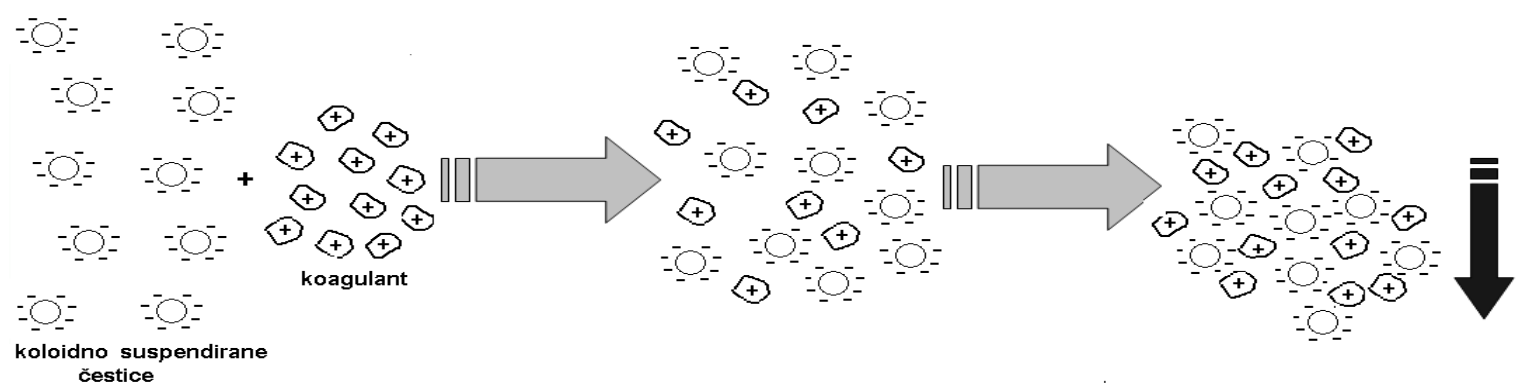

\section{Slika 1 - Pojednostavljeni prikaz procesa koagulacije i flokulacije}

Kako je već navedeno, destabilizaciju negativno nabijenih koloidnih čestica uzrokuje dodatak koagulanata. Koagulanti su kemijske tvari, odnosno metalne soli, koje u vodenom mediju hidroliziraju, pri čemu se oslobađaju kloridni ili sulfatni ioni i ioni vodika te nastaje voluminozni talog metalnog hidroksida. Tijekom navedene reakcije, oslobođeni sulfatni, kloridni ili vodikovi ioni neutraliziraju elektrostatski nabijene koloidne čestice te one poprimaju ulogu centra nukleacije na koji se vežu molekule nastalog voluminoznog taloga. Sve navedeno uzrokuje međusobno vezanje neutraliziranih koloidnih čestica u nakupine, tj. agregaciju, a potom, zbog povećanja mase i dimenzije čestica, njihovo taloženje [4,5]. U praksi kondicioniranja vode kao koagulanti se najčešće primjenjuju soli aluminija i željeza i to: aluminijev sulfat $\left(\mathrm{Al}_{2}\left(\mathrm{SO}_{4}\right)_{3} \times 18 \mathrm{H}_{2} \mathrm{O}\right)$, željezov klorid $\left(\mathrm{FeCl}_{3}\right)$, natrijev aluminat $\left(\mathrm{NaAlO}_{2}\right)$, željezov(II) sulfat $\left(\mathrm{FeSO}_{4} \times 7 \mathrm{H}_{2} \mathrm{O}\right)$ i željezov(III) sulfat $\left(\mathrm{Fe}_{2}\left(\mathrm{SO}_{4}\right)_{3}\right)$. Na učinkovitost pojedinog koagulanta u procesu kondicioniranja vode utječe niz čimbenika, od kojih su najvažniji fizikalno-kemijske karakteristike sirove vode, vrsta i doza koagulanta, vrijeme i brzina miješanja vode i koagulacijskog sredstva te primjena pomoćnih sredstava za flokulaciju. Utjecaj pojedinog navedenog čimbenika, kao i optimalna doza pojedinog koagulanta, ispituje se u laboratorijskim uvjetima pomoću Jar testa. Optimalnom dozom koagulanta smatra se najmanja doza kod koje doziranjem istog nastaje najviše flokula srednje veličine te mala količina sitnih čestica i najmanja mutnoća prije taloženja. Navedenim testom također je moguće odrediti optimalne vrijednosti i drugih procesnih parametara pri kojima će se postići najučinkovitije uklanjanje koloidnih čestica. Prevelike ili premale doze koagulanata nisu učinkovite jer mogu prouzrokovati nastanak koloidnih suspenzija $[3,5,6]$.

Prethodno je već navedeno da je vrijeme i brzina miješanja koagulanta i vode jedan od značajnih čimbenika koji utječu na konačni učinak procesa koagulacije i flokulacije pri kondicioniranju vode $[7,8,9]$. Naime, koagulacija, odnosno neutralizacija negativno nabijenih koloidnih čestica, bit će uspješnija ako se osigura intenzivno miješanje 
vode i koagulanta. Nasuprot tome, u fazi flokulacije, neophodno je smanjiti brzinu miješanja vode čime se osigurava lakše aglomeriranje neutraliziranih koloidnih čestica i nastalog voluminoznog taloga metalnog hidroksida. Kinetiku opisanih reakcija početkom 20. stoljeća je objasnio von Smoluchowski $[3,10,11]$, navodeći da su reakcije koje se događaju tijekom procesa koagulacije i flokulacije rezultat perkinetičkog i ortokinetičkog gibanja molekula te da, u konačnici, učinkovitost procesa ovisi o utrošenoj energiji i viskoznosti tekućine. Stoga je u ovom radu ispitan učinak vremena i brzine miješanja pri kondicioniranju aerirane podzemne vode, odnosno doziranju dva željezova koagulanta - željezova klorida $\left(\mathrm{FeCl}_{3}\right)$ i željezova(II) sulfata $\left(\mathrm{FeSO}_{4}\right)$. Učinak postupka određen je mjerenjem početne i završne količine organskih tvari, ukupne tvrdoće, alkaliteta i koncentracije ukupnog željeza, te pH vrijednosti i vodljivosti vode.

\section{Materijali i metode}

\subsection{Podzemna voda}

Uzorci podzemne vode, korišteni u ovom radu, uzeti su na vodocrpilištu „Jarčevac“ koje se nalazi 16 kilometara sjeverozapadno od grada Osijeka. Podzemna voda na vodocrpilištu "Jarčevac" crpi se s dubine od 104 m, potom se aerira, filtrira i dezinficira te se isporučuje potrošačima u obližnjim mjestima. Uzorci vode korišteni u eksperimentalnom dijelu ovoga rada zahvaćani su na ispustu nakon aeracije vode te su odmah dopremljeni u laboratorij na analizu i obradu. $U$ tablici 1 prikazane su prosječne vrijednosti fizikalno-kemijskih parametara korištene podzemne vode, izračunate na temelju rezultata monitoringa podzemne vode vodocrpilišta "Jarčevac" tijekom 2012. godine (četiri godišnje analize pojedinih fizikalno-kemijskih i mikrobioloških parametara).

\section{Tablica 1 - Prosječne vrijednosti parametara podzemne vode vodocrpilišta „Jarčevac“ i MDK vrijednosti}

\begin{tabular}{|c|c|c|c|}
\hline Parametar & mjerna jedinica & MDK vrijednosta & $\begin{array}{c}\text { podzemna voda s } \\
\text { vodocrpilišta „Jarčevac“ }\end{array}$ \\
\hline Temperatura & ${ }^{\circ} \mathrm{C}$ & 25 & 13.3 \\
\hline Mutnoća & NTU jedinica & 4 & 10.41 \\
\hline Miris & 1 & $\mathrm{Bez}$ & $\mathrm{Bez}$ \\
\hline pH vrijednost & $\mathrm{pH}$ jedinica pri $25^{\circ} \mathrm{C}$ & $6.5-9.5$ & 7.17 \\
\hline Vodljivost & $\mu \mathrm{S} / \mathrm{cm}$ pri $20^{\circ} \mathrm{C}$ & 2500 & 884.5 \\
\hline Oksidativnost & $\mathrm{mg} / \mathrm{L} \mathrm{O}_{2}$ & 3 & 4.58 \\
\hline Sumporovodik & $\mathrm{mg} / \mathrm{L} \mathrm{H}_{2} \mathrm{~S}$ & $\mathrm{Bez}$ & $<0.02$ \\
\hline Amonij & $\mathrm{mg} / \mathrm{L}\left(\mathrm{NH}_{4}{ }^{+}\right)$ & 0.50 & 1.6 \\
\hline Nitriti & $\mathrm{mg} / \mathrm{L} \mathrm{NO}_{2}^{-}$ & 0.10 & $<0.033$ \\
\hline Nitrati & ${\mathrm{mg} / \mathrm{L} \mathrm{NO}_{3}{ }^{-}}^{-}$ & 50 & $<3.0$ \\
\hline Hidrogenkarbonat & ${\mathrm{mg} / \mathrm{L} \mathrm{HCO}_{3}^{-}}^{-}$ & - & 605 \\
\hline Fluoridi & $\mu g / L F$ & - & 53.3 \\
\hline Kalcij & $\mathrm{mg} / \mathrm{L} \mathrm{Ca}^{2+}$ & - & 106 \\
\hline Kalij & $\mathrm{mg} / \mathrm{L} \mathrm{K}^{+}$ & 12 & 3.5 \\
\hline Natrij & $\mathrm{mg} / \mathrm{L} \mathrm{Na}^{+}$ & 150 & 53.0 \\
\hline Magnezij & $\mathrm{mg} / \mathrm{L} \mathrm{Mg}^{2+}$ & - & 26.3 \\
\hline Fosfati & $\mu \mathrm{g} / \mathrm{L} P$ & 300 & 120 \\
\hline Silikati, reaktivni & $\mathrm{mg} / \mathrm{L} \mathrm{SiO}_{2}$ & 20 & 16.4 \\
\hline Kloridi & ${\mathrm{mg} / \mathrm{L} \mathrm{Cl}^{-}}^{-}$ & 250 & 3.7 \\
\hline Sulfati & $\mathrm{mg} / \mathrm{L} \mathrm{SO}_{4}{ }^{2-}$ & 250 & $<4.6$ \\
\hline Arsen & $\mu \mathrm{g} / \mathrm{L}$ & 10 & 80.8 \\
\hline Željezo & $\mu \mathrm{g} / \mathrm{L}$ & 200 & 2771.8 \\
\hline Mangan & $\mu \mathrm{g} / \mathrm{L}$ & 50 & 135.7 \\
\hline Ukupni organski ugljik (TOC) & $\mathrm{mg} / \mathrm{L} \mathrm{C}$ & bez neuobičajenih promjena & 5.37 \\
\hline
\end{tabular}

a maksimalno dozvoljena koncentracija (MDK) prema Pravilniku o parametrima sukladnosti i metodama analize vode za ljudsku potrošnju (NN 125/2013) 
Iz navedene tablice vidljivo je da korištenu podzemnu vodu karakteriziraju povećane prosječne vrijednosti mutnoće, oksidativnosti, amonija, te arsena, željeza i mangana.

\subsection{Jar test i koagulanti}

Jar test je standardna metoda kojom se u laboratorijskim uvjetima određuju vrijednosti i utjecaj pojedinih ključnih čimbenika u procesu koagulacije i flokulacije na konačni učinak navedenog procesa kondicioniranja vode. U eksperimentalnom dijelu ovog rada korišten je uređaj za Jar test Floculateur 10405 (Bioblock Scientific) koji je prikazan na slici 2. Uređaj posjeduje 4 mješača (dimenzija $75.0 \mathrm{~mm} \times 25.0 \mathrm{~mm}$ ) s mogućnošću promjene vremena (0-30 $\mathrm{min})$ i broja okretaja miješanja (0 - $200 \mathrm{okr} / \mathrm{min})$.

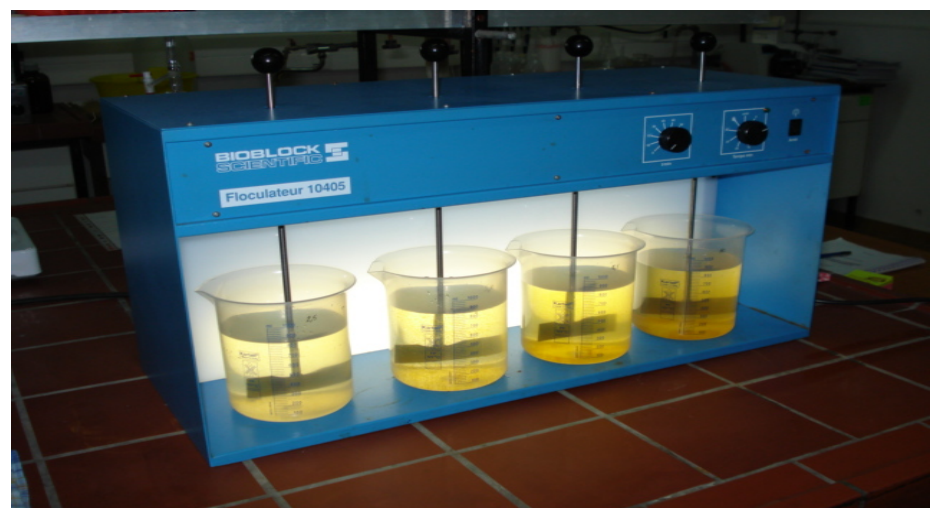

\section{Slika 2 - Uređaj za Jar test}

Podzemna voda i koagulanti su tijekom Jar testa miješani u polipropilenskim čašama (Kartell Labware division) dimenzija $270.0 \times 85.0 \mathrm{~mm}$. Prije provođenja Jar testa, uzorcima je ujednačena pH vrijednost na 7.5 doziranjem $0.1 \mathrm{M} \mathrm{HCl}$, odnosno $0.1 \mathrm{M} \mathrm{NaOH}$. Jar test se provodio u dva seta:

- Set I - doziranje koagulanta u $1000 \mathrm{ml}$ vode uz intenzivno miješanje u vremenu od 1 do 3 minute i 90 okretaja u minuti, a potom polagano miješanje u trajanju od 10 minuta i 15 okretaja u minuti

- Set II - doziranje koagulanta u $1000 \mathrm{ml}$ vode uz intenzivno miješanje u vremenu od 1 do 3 minute i 200 okretaja u minuti, a potom polagano miješanje u trajanju od 10 minuta i 15 okretaja u minuti.

Uzorci vode su potom mirovali pri čemu su se nastale flokule istaložile, a potom su uzorci profiltrirani preko filter papira $(0.45 \mu \mathrm{m})$.

Utjecaj miješanja na učinak koagulacije i flokulacije pri kondicioniranju vode ispitan je pomoću dva željezova koagulanta - željezova klorida i željezova(II) sulfata. Željezov klorid $\left(\mathrm{FeCl}_{3}\right)$ nabavljen je od tvrtke J.T. Baker-A Division of Mallinckrodt Baker, Inc., dok je željezov(II) sulfat $\left(\mathrm{FeSO}_{4}\right)$ nabavljen od tvrtke Acros Organics. Oba koagulanta su u vodu dozirana kao 1\%-tna otopina na način da je konačna koncentracija ukupnog željeza u uzorku iznosila $4 \mathrm{mg} / \mathrm{l}$. Svi pokusi provedeni su u dvije paralele, a kao konačni rezultati prikazane su srednje vrijednosti dobivenih rezultata.

\subsection{Analitičke metode}

Učinak primijenjenih koagulanata (željezova klorida i željezova(II) sulfata) pri obradi uzoraka aerirane podzemne vode praćen je određivanjem početnih i završnih vrijednosti sljedećih parametara: UV-apsorbancija pri $254 \mathrm{~nm}$, ukupna tvrdoća, alkalitet, koncentracija ukupnog željeza, pH vrijednost, vodljivost, a vizualno se pratio izgled i veličina nastalih flokula.

Više studija $[12,13,14]$ dokazalo je da aromatske skupine organskih tvari u vodi apsorbiraju UV zrake pri $254 \mathrm{~nm}$ te da se vrijednost apsorbancije $U_{254}$ može uzeti kao zamjenski pokazatelj količine otopljenog organskog ugljika (engl. dissolved organic carbon, COD). Stoga je učinkovitost uklanjanja organskih tvari primjenom željezova klorida, odnosno željezova(II) sulfata, određena mjerenjem vrijednosti $U_{254}$ polaznog uzorka aerirane podzemne vode i mjerenjem vrijednosti $U_{254}$ nakon obrade vode navedenim koagulantima. 
Mjerenje je provedeno pomoću UV-Vis spektrofotometra Specord 200 (Analitik Jena AG). Udio uklonjene organske tvari iz vode određen je pomoću formule:

$$
\text { uklonjena organska tvar }(\%)=\left(1-U_{\text {ov }} / U V_{N V}\right) \times 100
$$

gdje su:

UV ov izmjerena vrijednost apsorbancije $U_{254}$ obrađenog uzorka vode

$U V_{N V}$ izmjerena vrijednost apsorbancije $\mathrm{UV}_{254}$ neobrađene aerirane podzemne vode [15,16].

Ukupna tvrdoća početnih i završnih uzoraka određena je volumetrijskom metodom HRN ISO 6059:1998, dok je alkalitet određen titrimetrijskom metodom HRN EN ISO 9963-1:1998. Utjecaj miješanja u procesu koagulacije i flokulacije na ukupnu koncentraciju željeza praćen je spektrofotometrijskom metodom s 1,10-fenantrolinom (HRN ISO 6332:1998). pH vrijednost uzoraka vode prije i nakon obrade željezovim koagulantima praćena je laboratorijskim pH metrom Seven Easy (Mettler Toledo), metodom HRN ISO 10523:2009, dok je vodljivost istih određena metodom HRN EN 27888:2008 pomoću laboratorijskog konduktometra MA 5950 (Metrel).

\section{Rezultati i rasprava}

\subsection{Uklanjanje organskih tvari}

Prirodne organske tvari su kompleksna smjesa organskih spojeva čije karakteristike ovise o klimatskim uvjetima, geologiji i topografskim karakteristikama terena, no najčešće in čine spojevi kao što su polisaharidi, proteini, aminokiseline, ugljikovodici te huminske i fulvinske kiseline koje u povećanim koncentracijama uzrokuju pojavu boje i neugodni miris vode [17]. Osim navedenog, njihova pojava u vodi je nepoželjna jer, ako se voda naknadno dezinficira klorom, nastaju kancerogeni dezinfekcijski nusprodukti, takozvani trihalometani [5,6]. Stoga je poželjno da se tijekom procesa kondicioniranja vode što veća količina organskih tvari ukloni iz vode prije obveznog postupka dezinfekcije vode. Prethodno provedeno istraživanje na vodocrpilištu "Jarčevac“ (podatci nisu publicirani) radi uklanjanja organskih tvari iz podzemne vode primjenom ionskog izmjenjivača Amberlite (Rohm and Haas), pokazalo je gotovo 100\%-tni učinak pri uklanjanju organskih tvari, no zbog ekonomskih i ekoloških problema (značajna investicijska sredstva i problem zbrinjavanja zasićenog ionskog izmjenjivača) prednost ima konvencionalna metoda kao što je koagulacija i flokulacija.

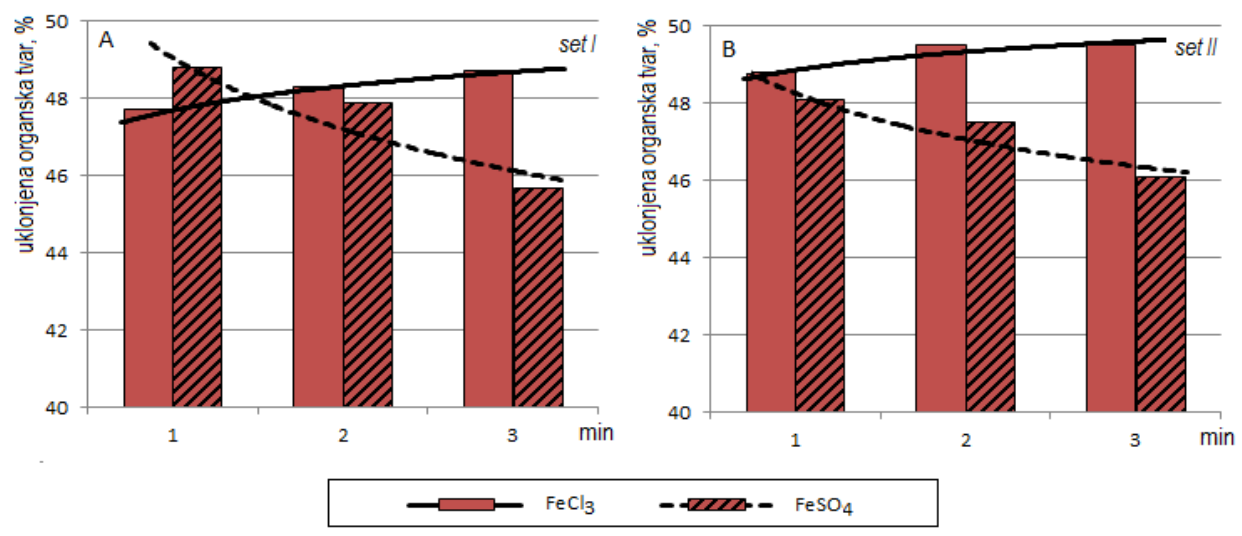

Slika 3 - Udjeli uklonjenih organskih tvari iz aerirane podzemne vode vodocrpilišta „Jarčevac“ primjenom željezova klorida $\left(\mathrm{FeCl}_{3}\right)$ i željezova(II) sulfata $\left(\mathrm{FeSO}_{4}\right)$

Stoga je u ovome radu ispitan utjecaj brzine i vremena miješanja u procesu obrade vode koagulacijom i flokulacijom na učinkovitost željezova klorida i željezova(II) sulfata pri uklanjanju organskih tvari iz uzoraka podzemne vode vodocrpilišta "Jarčevac" Jar testom u dva seta pokusa. U setu I koagulanti su dozirani u $1000 \mathrm{ml}$ 
vode uz intenzivno miješanje od 90 okretaja u minuti i vremenu od 1 do 3 minute (slika 3a), dok su u drugom setu koagulanti dozirani u $1000 \mathrm{ml}$ vode uz intenzivno miješanje od 200 okretaja u minuti u vremenu od 1 do 3 minute (slika $3 b$ ). $U$ oba seta je nakon intenzivnog miješanja uslijedilo polagano miješanje od 15 okretaja mješača u minuti u trajanju od 10 minuta. Uzorci su potom ostavljeni da se istalože, a nastale netopive flokule željezova hidroksida su profiltrirane. Svi pokusi su provedeni pri početnoj koncentraciji željeza od $4 \mathrm{mg} / \mathrm{l}$ i početnoj pH vrijednosti vode od 7.5. Vizualnim praćenjem uočeno je da su pri doziranju oba koagulanta nastale flokule podjednakih veličina.

Kako je vidljivo na slici 3a i 3b, u oba seta postignut je približno jednak učinak uklanjanja organskih tvari doziranjem ispitivanih željezovih koagulanata, no zamjetno je da je produženo vrijeme intenzivnog miješanja pri doziranju željezova klorida u oba seta pozitivno utjecalo i povećalo udio uklonjene organske tvari, dok je pri doziranju željezova(II) sulfata udio uklonjenih organskih tvari u oba seta produžavanjem perioda intenzivnog miješanja opadao. Usporedbom udjela uklonjenih organskih tvari prikazanih na slici $3 a$ i $3 b$, vidljivo je da su veći udjeli organskih tvari uklonjeni u setu II, u kojem su uzorci vode i koagulanti intenzivnije miješani (200 okr $/ \mathrm{min})$. Tako je u setu I pri doziranju $\mathrm{FeCl}_{3}$ najviše uklonjeno 48.7\%, a u setu II 49.5\%. Pri doziranju $\mathrm{FeSO}_{4}$, udio organskih tvari je opadao pri dužem trajanju miješanja te je u setu I najviše uklonjeno $45.7 \%$, odnosno $48.1 \%$ u setu II.

Nekoliko studija je, prateći vrijednosti više parametara kakvoće vode, ispitalo i potvrdilo utjecaj brzine miješanja na učinak koagulacije i flokulacije pri kondicioniranju vode $[9,18,19]$. Tako Lin i suradnici [9], ispitujući povezanost početne mutnoće (200 NTU, 15 NTU) i brzine miješanja vode pri doziranju koagulanta, navode da je utvrđena značajna korelacija između brzine miješanja vode pri doziranju koagulanta i završne kakvoće vode, naročito kod uzoraka vode $s$ manjom početnom mutnoćom. Navedenu korelaciju objašnjavaju utjecajem povećane brzine miješanja na proces međusobnog sudaranja čestica i njihove agregacije u vodi, što rezultira nastankom većih flokula i njihovim lakšim izdvajanjem iz vode naknadnom filtracijom. U slučaju visoke vrijednosti početne mutnoće vode, autori navode da povećanje brzine miješanja u fazi koagulacije uzrokuje nastanak flokula manjih dimenzija te da duže vrijeme intenzivnog miješanja dodatno dezintegrira nastale flokule, što smanjuje učinak filtracije pri izdvajanju flokula iz vode [9]. Prateći učinak brzine miješanja vode i koagulanta na bazi aluminijevih soli na udio uklonjenih organskih tvari, Lin i suradnici [9] također navode da povećanje brzine miješanja uzorka manje početne mutnoće ubrzava adsorpciju prirodnih organskih tvari na površinu nastalog taloga $\mathrm{Al}(\mathrm{OH})_{3}$ što za posljedicu ima i njihovo učinkovitije izdvajanje iz vode.

Dakle, zbog svega prethodno navedenog, moguće je zaključiti da je učinkovitije uklanjanje organskih tvari pri doziranju željezovog klorida rezultat brže reakcije nastanka molekula $\mathrm{Fe}(\mathrm{OH})_{3}$ na čiju površinu se adsorbiraju organske tvari. Naime, literatura [20] navodi da pri doziranju željezova klorida dolazi to trenutačnog formiranja netopivog taloga $\mathrm{Fe}(\mathrm{OH})_{3}$, dok pri doziranju željezova(II) sulfata u prvoj reakciji nastaje topivi $\mathrm{Fe}(\mathrm{OH})_{2}$ kojega je potrebno dodatno oksidirati da bi nastao netopivi $\mathrm{Fe}(\mathrm{OH})_{3}$. Može se zaključiti da su, zbog manje molekularne mase i topivosti, flokule $\mathrm{Fe}(\mathrm{OH})_{2}$ podložnije dezintegraciji kod produženog vremena intenzivnog miješanja, što je negativno utjecalo na adsorpciju prirodnih organskih tvari na površinu $\mathrm{Fe}(\mathrm{OH})_{2}$, kao i njihovo izdvajanje iz vode filtracijom.

\subsection{Utjecaj na ukupnu tvrdoću vode}

U ovom radu praćen je i utjecaj brzine i vremena miješanja koagulanta i vode na ukupnu tvrdoću vode, a dobiveni rezultati prikazani su na slici 4. Tvrdoća vode je definirana kao zbroj polivalentnih kationa prisutnih u vodi, a izražava se kao ekvivalent količine kalcijeva karbonata [6]. Ukupnu tvrdoću vode čine sve kalcijeve i magnezijeve soli, i to prije svega njihovi hidrogenkarbonati i karbonati te sulfati, kloridi, nitrati i silikati [4]. Kako čestice kalcijeva karbonata također posjeduju negativan naboj, primjenom kationskih koagulanata može doći do djelomičnog mekšanja vode [18].

Početna vrijednost ukupne tvrdoće korištenih uzoraka aerirane podzemne vode s vodocrpilišta "Jarčevac“ iznosila je $375 \mathrm{mg} \mathrm{CaCO} / \mathrm{l}$, što ovu podzemnu vodu prema klasifikacijskoj skali American Water Work Association [6] svrstava u kategoriju vrlo tvrdih voda. Kao što je vidljivo na slici 4a i 4b, ukupna tvrdoća vode pri doziranju obje vrste koagulanta i pri svim ispitanim vremenima miješanja bila je manja od navedene početne vrijednosti, odnosno, došlo je do djelomičnog mekšanja vode. 


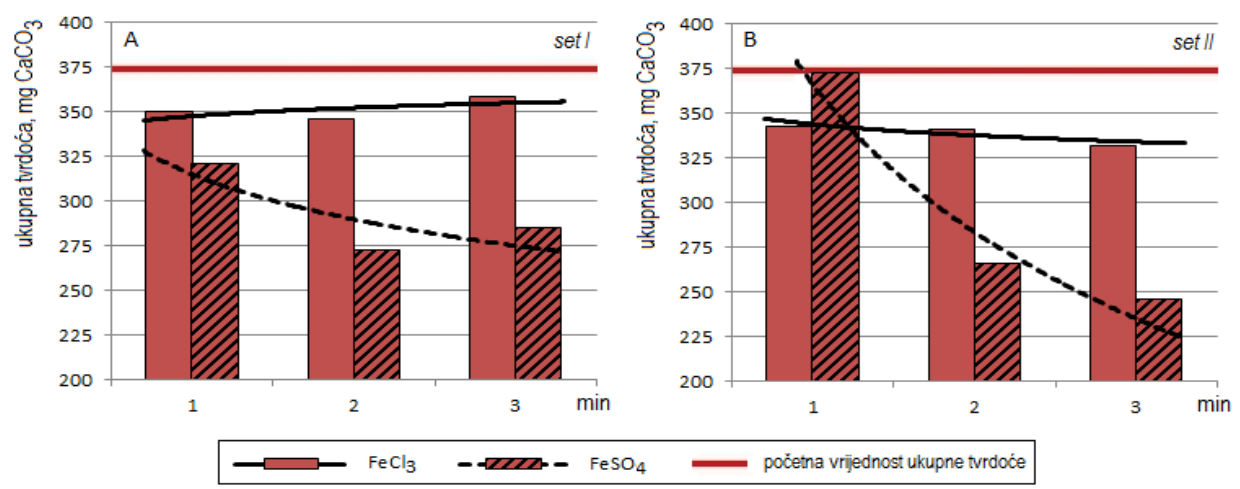

Slika 4 - Ukupna tvrdoća uzoraka podzemne vode vodocrpilišta „Jarčevac“ nakon primjene željezova klorida $\left(\mathrm{FeCl}_{3}\right)$ i željezova(II) sulfata $\left(\mathrm{FeSO}_{4}\right)$

Ipak, zamjetno je da je značajnije mekšanje vode postignuto primjenom željezova(II) sulfata, a da je duži period intenzivnog miješanja željezovog(II) sulfata i podzemne vode imao pozitivan učinak na smanjenje tvrdoće vode u oba seta ispitivanja. Tako je u setu II (200 okr/min, 3 minute), doziranjem željezova(II) sulfata, ukupna tvrdoća vode pri posljednjem, najdužem miješanju smanjena s početnih 375 na $246 \mathrm{mg} \mathrm{CaCO} / /$. Primjenom željezova klorida u oba seta ispitivanja i pri svim periodima intenzivnog miješanja, postignuto je ujednačeno smanjenje ukupne tvrdoće vode. Najmanje smanjenje ukupne tvrdoće vode doziranjem željezova klorida (sa 375 na $358 \mathrm{mgCaCO}_{3} /$ l) postignuto je u setu I (90 okr/min, $\left.3 \mathrm{~min}\right)$, dok je najveće mekšanje vode postignuto (332 $\left.\mathrm{mgCaCO}_{3} / \mathrm{l}\right)$ u setu I/ pri najdužem periodu miješanja (200 okr/min, $3 \mathrm{~min}$ ).

\subsection{Utjecaj na alkalitet vode}

Alkalitet predstavlja kvantitativnu sposobnost vodenog medija da reagira s vodikovim ionima, a na vrijednost alkaliteta vode utječe koncentracija hidroksida, karbonata i bikarbonata te alkalijski i zemnoalkalijski metali, uglavnom natrij, kalij, kalcij i magnezij [10]. Alkalitet vode ima značajnu ulogu na konačni učinak procesa koagulacije i flokulacije jer, ako prirodna vrijednost alkaliteta vode nije optimalna za pojedinu vrstu koagulanta, potrebno ju je korigirati, i to najčešće doziranjem hidratiziranog vapna [3]. Literatura [20] također navodi da je povećani alkalitet vode naročito poželjan pri uporabi željezova(II) sulfata te se često u praksi pri doziranju navedenog koagulanta dozira i vapno. Pritom u reakciji između željezova(II) sulfata i kalcijeva hidroksida nastaje $\mathrm{Fe}(\mathrm{OH})_{2}$, a potom, u oksidacijskim uvjetima, i netopivi $\mathrm{Fe}(\mathrm{OH})_{3}$. Isti izvor opisuje i reakcije koje se odvijaju pri doziranju željezovog klorida te navodi da se i u tom slučaju odvija reakcija između navedenog koagulanta i kalcijeva hidroksikarbonata [20].

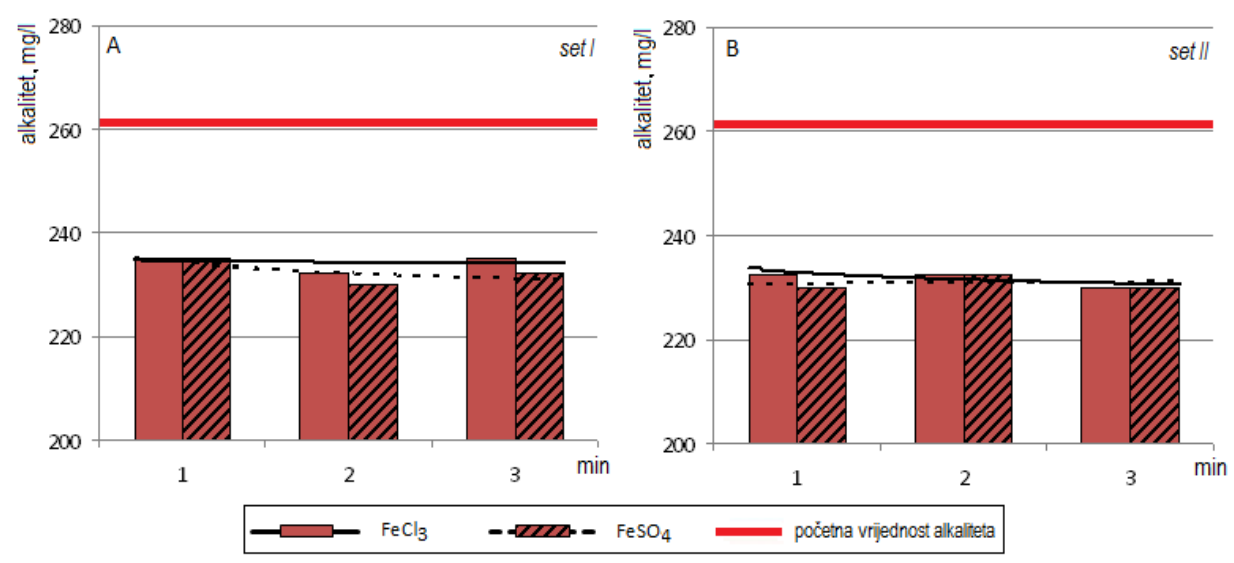

Slika 5 - Alkalitet uzoraka podzemne vode vodocrpilišta „Jarčevac“ nakon primjene željezova klorida $\left(\mathrm{FeCl}_{3}\right)$ i željezova(II) sulfata $\left(\mathrm{FeSO}_{4}\right)$ 
Utjecaj miješanja pri doziranju željezova klorida i željezova(II) sulfata u aeriranu podzemnu vodu vodocrpilišta "Jarčevac" na završni alkalitet vode prikazan je na slici 5. Početni alkalitet korištenih uzoraka podzemne vode iznosio je $262.5 \mathrm{mg} / \mathrm{l}$. Kao što je prikazano na slici $5 \mathrm{a}$, u setu I, primjenom oba željezova koagulanta, postignuti su približno jednaki rezultati i završna vrijednost alkaliteta je bila od $235 \mathrm{mg} / \mathrm{l}\left(\mathrm{FeCl}_{3}, 90\right.$ okr/min, 1 i $3 \mathrm{~min}$ ) do $230 \mathrm{mg} / \mathrm{l}\left(\mathrm{FeSO}_{4}, 90 \mathrm{okr} / \mathrm{min}, 1\right.$ i $\left.3 \mathrm{~min}\right)$, dok je u setu II, pri doziranju oba koagulanta, završna vrijednost alkaliteta bila između 232.5 i $230 \mathrm{mg} / \mathrm{l}$ (slika $5 \mathrm{~b}$ ). Dobiveni rezultati posljedica su u prethodnom dijelu već opisanih reakcija između doziranih željezovih koagulanata i u vodi prisutnih kalcijevih hidrogenkarbonata [20].

\subsection{Utjecaj na koncentraciju ukupnog željeza u vodi}

Početna koncentracija ukupnog željeza u korištenim uzorcima aerirane podzemne vode vodocrpilišta „Jarčevac" iznosila je $2900 \mu \mathrm{g} / \mathrm{l}$, dok je prema Pravilniku o parametrima sukladnosti i metodama analize vode za ljudsku potrošnju [1] dozvoljeno najviše $200 \mu \mathrm{g} / \mathrm{l}$. Utjecaj brzine i vremena miješanja na završnu koncentraciju ukupnog željeza, pri doziranju željezova klorida i željezova(II) sulfata, prikazan je na slici 6.

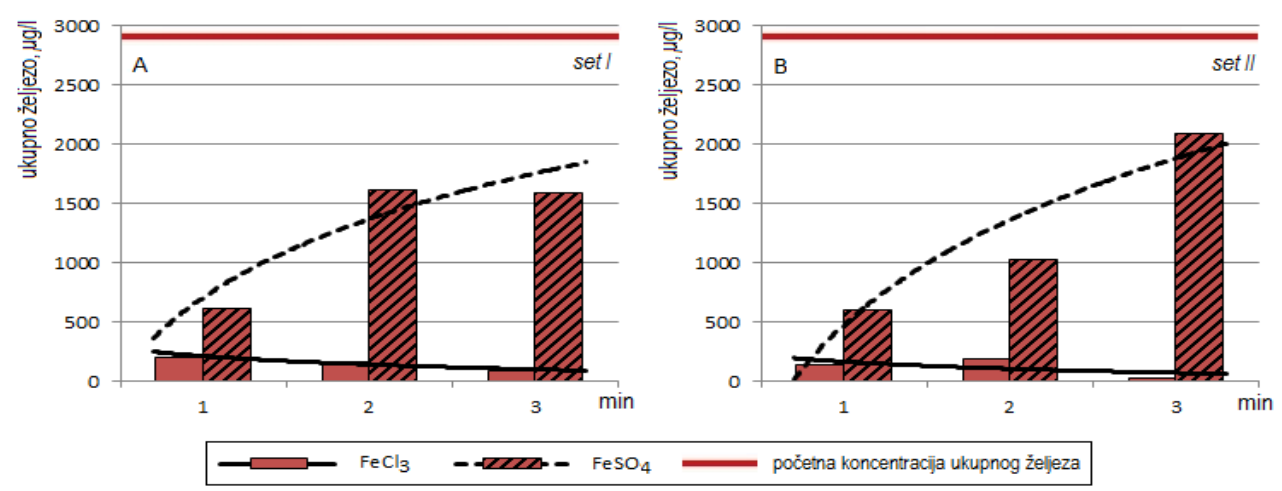

\section{Slika 6 - Koncentracije ukupnog željeza u uzorcima podzemne vode vodocrpilišta „Jarčevac“ nakon primjene željezova klorida $\left(\mathrm{FeCl}_{3}\right)$ i željezova(II) sulfata $\left(\mathrm{FeSO}_{4}\right)$}

$\mathrm{U}$ oba seta ispitivanja, doziranje $\mathrm{FeCl}_{3} \mathrm{u}$ vodu uzrokovalo je značajno smanjenje početne koncentracije ukupnog željeza te su završne koncentracije ukupnog željeza bile u rasponu od 21 do $203 \mu \mathrm{g} / \mathrm{l}$, dok su pri doziranju $\mathrm{FeSO}_{4}$ završne koncentracije ukupnog željeza u oba seta bile iznad MDK vrijednosti propisane navedenim Pravilnikom (od 600 do $1622 \mu \mathrm{g} / \mathrm{l}$ ). Povećane završne koncentracije ukupnog željeza u obrađenim uzorcima podzemne vode kod primjene željezova(II) sulfata su očekivane, s obzirom na već prethodno opisane reakcije koje se odvijaju pri doziranju željezova(II) sulfata, odnosno nastanak djelomično topivog $\mathrm{Fe}(\mathrm{OH})_{2}$. Produženo vrijeme intenzivnog miješanja dodatno je povećalo završnu koncentraciju ukupnog željeza u vodi, što potvrđuje prethodno navedeni zaključak da je ono uzrokovalo dezintegraciju flokula $\mathrm{Fe}(\mathrm{OH})_{2}$ i povećalo njegovu topivost.

\subsection{Utjecaj na pH vrijednost vode}

Početna pH vrijednost vode jedan je od najznačajnijh parametara koji utječu na učinkovitost procesa koagulacije i flokulacije. Stručna literatura [3] navodi da doziranje koagulanata na bazi mineralnih soli može uzrokovati promjenu pH vrijednosti vode jer se u reakciji hidrolize koagulanata oslobađaju ioni vodika te kloridni ili sulfatni ioni, odnosno, vežu se ioni hidrokarbonata. Ispitivanja su pokazala da svi, u uvodnom dijelu navedeni koagulanti, najučinkovitije djelovanje imaju pri određenim pH vrijednostima vode. Tako se navodi da pri doziranju $\mathrm{FeCl}_{3}$, do nastajanja flokula dolazi već pri pH 4, ali da je optimalno pH područje djelovanja željezova klorida između $5.5 \mathrm{i}$ 6.5, te između 8 i 9 . Kao optimalno pH područje za djelovanje željezova(II) sulfata navodi se pH iznad 8.5 [21]. $\mathrm{pH}$ vrijednost vode nakon koagulacija i flokulacije te naknadne filtracije također ima značajnu ulogu pri daljnjim postupcima obrade vode jer se tada voda u pogonu najčešće prihvaća u vodospreme iz kojih se distribuira u 
vodoopskrbnu mrežu, a pri tome se provodi postupak dezinfekcije. Da bi postupak dezinfekcije vode bio što učinkovitiji, poželjno je da je pH vrijednost vode blago kisela (optimalna je oko pH 6), jer alkalna sredina smanjuje baktericidno djelovanje klora [21].

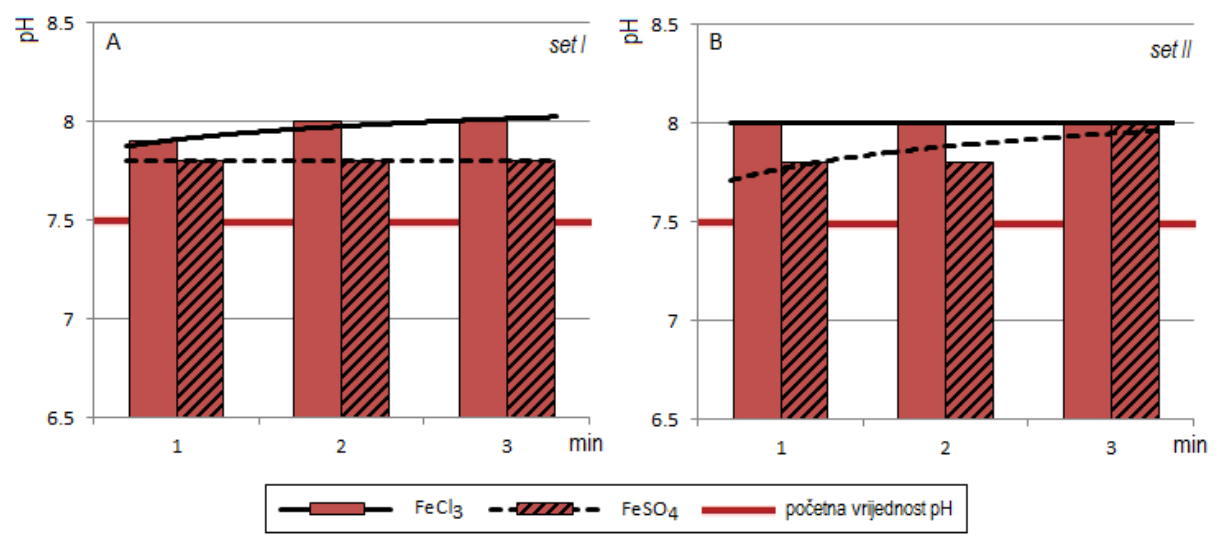

\section{Slika 7- pH vrijednosti uzoraka podzemne vode vodocrpilišta „Jarčevac" nakon primjene željezova klorida $\left(\mathrm{FeCl}_{3}\right)$ i željezova(II) sulfata $\left(\mathrm{FeSO}_{4}\right)$}

Mjerenjem početnih pH vrijednosti korištenih uzoraka aerirane podzemne vode utvrđeno je da se ona kreće između 7.2 i 7.8 te je, zbog usporedivosti rezultata, prije doziranja otopine koagulanta u podzemnu vodu, svim uzorcima vode podešena početna pH vrijednost od 7.5. Nakon obrade vode izmjerene su završne pH vrijednosti, a dobiveni rezultati su prikazani na slici 7. Iz navedenog prikaza vidljivo je da su u oba seta postignuti gotovo identični rezultati. Tako je završna pH vrijednost vode pri doziranju željezova klorida bila između 7.9 i 8.0, a pri doziranju željezova(II) sulfata najčešće 7.8. Sve navedene vrijednosti su bile u skladu s odredbama Pravilnika 0 parametrima sukladnosti i metodama analize vode za ljudsku potrošnju [1].

\subsection{Utjecaj na vodljivost vode}

Tvari koje se otapaju u vodi u obliku iona imaju sposobnost provođenja električne struje. Vrijednost vodljivosti, odnosno količina provedene struje, ovisi o koncentraciji iona u vodi te se, zbog toga, parametar vodljivosti uzima kao indirektan pokazatelj ukupno otopljenih soli u vodi [3]. Prema Pravilniku o parametrima sukladnosti i metodama analize vode za ljudsku potrošnju [1] maksimalno dozvoljena vrijednost vodljivosti iznosi $2500 \mu \mathrm{S} / \mathrm{cm}$.

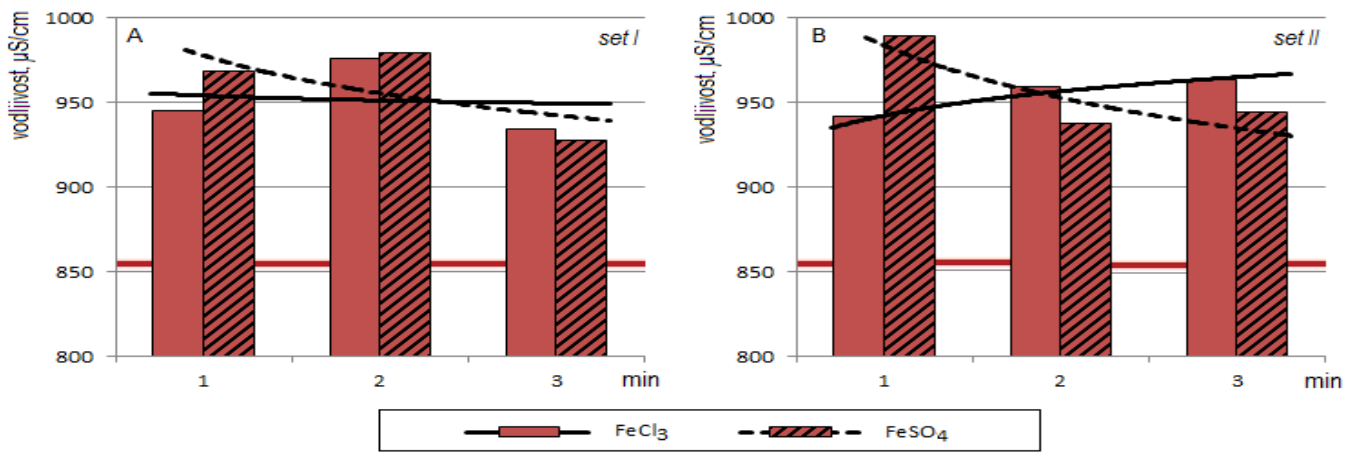

\section{Slika 8 - Vodljivost uzoraka podzemne vode vodocrpilišta „Jarčevac“ nakon željezova klorida $\left(\mathrm{FeCl}_{3}\right)$ i željezova(II) sulfata $\left(\mathrm{FeSO}_{4}\right)$}

$\mathrm{U}$ ovome radu praćen je utjecaj brzine i vremena miješanja koagulanata $\left(\mathrm{FeCl}_{3}\right.$ i $\left.\mathrm{FeSO}_{4}\right)$ i vode na završnu vodljivost vode, a dobiveni rezultati su prikazani na slici 8 . Početna vodljivost uzoraka aerirane podzemne vode $s$ 
vodocrpilišta „Jarčevac“ iznosila je $855 \mu \mathrm{S} / \mathrm{cm}$. Na slici 8 vidljivo je da je u oba seta došlo do povećanja vodljivosti vode u odnosu na njezinu početnu vrijednost, što je uzrokovano povećanjem koncentracije iona u vodi zbog hidrolize dodanih koagulanata. Vrijednosti vodljivosti su varirale kod primjene oba koagulanta te su u setu I bile između 927 i $979 \mu \mathrm{S} / \mathrm{cm}$, dok su u setu II bile između 937 i $989 \mu \mathrm{S} / \mathrm{cm}$. Sve navedene najviše i najniže vrijednosti postignute su pri doziranju $\mathrm{FeSO}_{4}$, ali oscilacije završnih vrijednosti vodljivosti vode jednako su utvrđene i pri doziranju $\mathrm{FeCl}_{3}$.

\section{Zaključci}

$\mathrm{U}$ ovome radu je Jar testom ispitan utjecaj brzine i vremena miješanja dva koagulanta $\left(\mathrm{FeCl}_{3} \mathrm{i} \mathrm{FeSO}_{4}\right)$ na učinkovitost koagulacije i flokulacije pri kondicioniranju aerirane podzemne vode vodocrpilišta "Jarčevac". Utjecaj brzine miješanja na učinak postupka ispitan je pri početnoj pH vrijednosti vode od 7.5 , a primijenjeni koagulanti su dozirani kako bi početna koncentracija ukupnog željeza u uzorcima vode iznosila $4 \mathrm{mg} / \mathrm{L}$. Učinkovitost postupka praćena je određivanjem polaznih i završnih vrijednosti količine organskih tvari, ukupne tvrdoće, alkaliteta i koncentracije ukupnog željeza te pH vrijednosti i vodljivosti vode, a dobiveni rezultati su sljedeći:

(1) najveći udjeli prirodnih organskih tvari uklonjeni su u oba seta pri doziranju $\mathrm{FeCl}_{3}$ (najviše 49.5\%)

(2) značajnije mekšanje vode postignuto je u oba seta pri doziranju $\mathrm{FeSO}_{4}$

(3) završni alkaliteti vode imali su približno jednake vrijednosti pri doziranju oba koagulanta

(4) završne koncentracije ukupnog željeza jedino su pri uporabi $\mathrm{FeCl}_{3}$ bile u skladu s odredbama Pravilnika o parametrima sukladnosti i metodama analize vode za ljudsku potrošnju (NN 125/2013)

(5) $\mathrm{pH}$ vrijednosti vode su nakon obrade u oba seta bile ujednačene te su pri doziranju $\mathrm{FeCl}_{3}$ iznosile 8.0, a pri doziranju $\mathrm{FeSO}_{4}$, uglavnom 7.8

(6) završne vrijednosti vodljivosti vode oscilirale su u oba seta i pri doziranju oba koagulanta te su bile iznad početne vodljivosti sirove vode.

\section{Literatura}

[1] Pravilnik o parametrima sukladnosti i metodama analize vode za ljudsku potrošnju (NN 125/2013)

[2] Council Directive 98/83/EC of 2 November 1998 on the quality of water intended for human consumption, Official Journal of the European Communities 5.12.98

[3] Gulić, I. 2003. Kondicioniranje vode, HSGI, Zagreb

[4] Mijatović, I.; Matošić, M. 2007.Tehnologija vode, PBF, Zagreb

[5] Sincero A.P.; Sincero G.A. 2003. Physical-chemical treatment of water and wastewater, IWA-CRC Press, Washington D.C.

[6] American Water Works Association. 1999. Water Quality and Treatment, McGraw-Hill, Inc., New York

[7] Reynolds, T.D.; Richards, P.A. 1995. Unit Operations and Processes in Environmental Engineering, 2nd Edition, PWS Publ, Boston.

[8] Kawamura, S. 2002. Design of basic treatment process units, in: Integrated Design and Operation of Water Treatment Facilities, John Wiley and Sons, New York.

[9] Lin, J.L.; Pan, J.R.; Huang, C. 2013. Enhanced particle destabilization and aggregation by flash-mixing coagulation for drinking water treatment. Separation and Purification Technology, Volume 115, pp 145151.

[10] Von Smoluchowski, M. 1916. Drei Vorträge über Diffusion, Brownsche Molekularbewegung und Koagulation von Kolloidteilchen. Physikalische Zeitschrift, Volume 17, pp 557-571.

[11] Von Smoluchowski M. 1917. Versuch einer mathematischen theorie der koagulationskinetic kolloider losungen. Zeitschrift für Physikalische Chemie, Volume 92, pp 129-168.

[12] Hur, J.; Williams, M.A.; Schlautman, M.A. 2006. Evaluating spectroscopic and chromatographic techniques to resolve dissolved organic matter via end member mixing analysis. Chemosphere, Volume 63, pp 387402 
[13] Korshin, G.; Chow, C.W.K.; Fabris, R.; Drikas, M. 2009. Absorbance spectroscopy based examination of effects of coagulation on the reactivity of fractions of natural organic matter with varying apparent molecular weights. Water Research, Volume 43, pp 1541-1548

[14] Matilainen, A.; Gjessing, E.T.; Lahtinen, T.; Hed, L.; Bhatnagar, A.; Sillanpää, M. 2011. An overview of the methods used in the characterization of natural organic matter (NOM) in relation to drinking water treatment. Chemosphere, Volume 83, pp 1431-1442

[15] American Water Works Association. 1999. Standard Methods for the Examination of Water and Wastewater. 3rd Edition, American Water Works Association and Water Pollution Control Federation, Washington D.C.

[16] Kuleš, M.; Habuda-Stanić, M. 2000. Analiza vode, Prehrambeno-tehnološki fakultet, Osijek

[17] Habuda-Stanić, M.; Romić, Ž.; Nujić, M.; Santo, V.; Kuveždić, Z. 2013. Effects of activated carbon types on NOM removal effect from natural waters. Technologica Acta. Volumen 6, pp 29-37

[18] Park, S.M.; Jun, H.B.; Jung, M.S.; Koo, H.M. 2006. Effects of velocity gradient and mixing time on particle growth in a rapid mixing tank, Water Science and Technology. Volume 53, pp 95-102

[19] Clark, M.M.; Srivastava, R.M. 1994. Selection and design of mixing processes for coagulation, AWWARF, Denver

[20] Bratby, J. 2008. Coagulation and Flocculation in Water and Wastewater Treatment, 2nd edition, IWA Publishing, London

[21] Kemmer, F.N. 2005. Nalkov priručnik za vodu, Drugo izdanje, Građevinska knjiga, Beograd

[22] Korać, V. 1985. Tehnologija vode za potrebe industrije, Udruženje za tehnologiju vode, Beograd 